\title{
Filsafat Ilmu dalam Lingkup Agama dan Kebudayaan, Peran Ilmu dalam Pengembangan Agama, Peran Agama dalam Pengembangan Ilmu
}

\author{
Citra Kurniawan \\ Sekolah Tinggi Teknik Malang \\ airakurniawan@gmail.com
}

\begin{abstract}
ABSTRAK
Perkembangan ilmu memiliki dua sisi yaitu sisi yang berdampak positif dan berdampak negative. Ilmu memiliki dampak positif karena dapat memperbaiki kualitas hidup manusia seperti implementasi ilmu dalam bidang komunikasi, transportasi, medis dan sarana industri. Ilmu memiliki dampak negatif jika dapat merugikan dan membahayakan martabat manusia, sehingga diperlukan tatanan ajaran Agama untuk memberikan petunjuk. Selain itu keragaman kebudayaan dalam suatu negara turut mempengaruhi perkembangan ilmu dikarenakan kebutuhan dan keinginan masing-masing penduduk berbeda
\end{abstract}

Kata Kunci : Ilmu, Kebudayaan, Agama, Filsafat Ilmu

\section{PENDAHULUAN}

Ilmu pengetahuan, agama dan filfasat merupakan tiga aspek yang dapat menuntun manusia mencari kebenaran, meskipun ketiga aspek tersebut tidak dapat dikategorikan sesuatu hal yang sama. Secara umum, filsafat merupakan salah satu kegiatan atau hasil kegiatanyang menyangkut aktivitas dan olah budi manusia. ${ }^{1}$ Agama merupakan hal yang berkaitan dengan dengan masalah hubungan manusia dan dunianya dengan Allah. ${ }^{2}$ Segala sesuatu yang berasal dari Tuhan, dalam perspektif agama adalah sebuah kebenaran yang tidak dapat ditolak. Sedangkan ilmu adalah deskripsi total dan konsisten dari fakta - fakta empiris yang merumuskan secara bertanggung jawab dalam istilah - istilah yang sesederhana mungkin. ${ }^{3}$ Ketiga aspek memberikan kontribusi kepada manusia dalam proses penyelesaian masalah. Ilmu pengetahuan pada saat ini berkembang dengan pesat seiring dengan perkembangan pemikiran manusia. Dengan ilmu pengetahuan manusia dapat memecahkan masalah dan memudahkan manusia mencapai tujuan.

Hakikat seorang manusia adalah untuk mencari kebenaran karena dibekali oleh Allah SWT dengan akal pikiran yang dibimbing oleh nilai - nilai agama. Ketiga aspek yang digunakan untuk mencari kebenaran di atas memiliki titik persamaan, titik perbedaan, dan hubungan antara satu dengan lainnya. ${ }^{4}$ Adapun penjelasannya adalah sebagai berikut :

\footnotetext{
${ }^{1}$ Soegiono, Tamsil Muis, Filsafat Pendidikan, (Bandung: Remaja Rosdakarya, 2012), hal. 17.

${ }^{2}$ Lorens Bagus, Kamus Filsafat, (Jakarta: Gramedia, 1996), hal. 12.

${ }^{3}$ J. Arthur Thompson, "An Introduction to Science" dalam Abd. Wahid, Korelasi Agama, Filsafat Dan Ilmu, (Banda Aceh : Fakultas Ushuluddin IAIN Ar-Raniry, 2012), hal. 225.

${ }^{4}$ Pirhat Abbas, Hubungan Filsafat, Ilmu, Dan Agama, (Media Akademika Volume 25, No. 2, 2010), hal. 138.
} 


\section{a. Titik Persamaan}

Filsafat, ilmu pengetahuan dan agama bertujuan untuk kebenaran dan bertindak atas rumusan mengenai suatu kebenaran. Filsafat berusaha mencari kebenaran dengan jalan menggunakan akal, pikiran dan logika, ilmu pengetahuan mencari kebenaran dengan menggunakan metode ilmiah melalui penelitian, sedangkan agama berusaha menjelaskan kebenaran melalui wahyu Tuhan.

\section{b. Titik Perbedaan}

Filsafat dan ilmu pengetahuan kedua-duanya adalah sama-sama bersumber kepada ra'yu (akal, pikiran, budi, rasio, nalar dan reason) manusia untuk mencari kebenaran.

Sedangkan agama berusaha mengungkapkan, menjelaskan dan membenarkan suatu kebenaran adalah bersumber dari wahyu. Ilmu mencari kebenaran berdasarkan metode (riset), pengalaman (empiris) dan percobaan (eksperimen). Sedangkan manusia dalam mencari kebenaran terhadap agama itu dengan jalan atau mempertanyakan (dalam upaya mencari kebenaran) terhadap berbagai masalah dari kitab suci dan firman Illahi.

c. Hubungan

Tidak semua permasalahan dapat dipecahkan oleh ilmu pengetahuan karena ilmu pengetahuan yang terbatas, terbatas subyek dan objeknya (baik objek materi maupun objek forma), dan terbatas juga oleh metodologinya. Kemudian permasalahan - permasalah yang tidak terjawab oleh ilmu pengetahuan coba untuk dijawab oleh filsafat. Tidak semua masalah yang tidak atau belum terjawab oleh filsafat, lantas dengan sendirinya dapat dijawab oleh agama. Agama hanya memberi jawaban tentang banyak persoalan asasi yang sama sekali tidak terjawab oleh ilmu pengetahuan, dan filsafat.

\section{Agama dan Kebudayaan}

Dalam kehidupan bermasyarakat,agama dan kebudayaan adalah dua hal yang dekat implementasinya meskipun agama dan kebudayaan bukan merupakan kesatuan yang utuh. Dalam kaidah, sebenarnya agama dan kebudayaan mempunyai kedudukan masingmasing dan tidak dapat disatukan, karena agamalah yang mempunyai kedudukan lebih tinggi dari pada kebudayaan. Namun keduanya mempunyai hubungan yang erat dalam

\footnotetext{
${ }^{5}$ Laode Monto Bauto, Perspektif Agama Dan Kebudayaan Dalam Kehidupan Masyarakat Indonesia, (Kendari: Jurnal Pendidikan Ilmu Sosial, 2014)
} 
kehidupan masyarakat. Pemahaman masyarakat terhadap perubahan kehidupan jika dilihat dari aspek agama dan kebudayaan memiliki hubungan yang terikat satu sama lain selama masyarakat dapat menempatkan posisi agama dan posisi budaya dalam kehidupan. Agama dan budaya berjalan beriringan sehingga memiliki hubungan yang erat dalam dialektikanya. Agama sebagai pedoman hidup manusia yang diciptakan oleh Tuhan, dalam menjalani kehidupannya. Sedangkan kebudayaan adalah sebagai kebiasaan tata cara hidup manusia yang diciptakan oleh manusia itu sendiri dari hasil daya cipta, rasa dan karsanya yang diberikan oleh Tuhan. ${ }^{5}$

\section{Agama}

Agama diidentikkan dengan kepercayaan, keyakinan dan sesuatu yang menjadi anutan. Konsepsi agama menurut kamus besar bahasa indonesia adalah sistem yang mengatur tata keimanan (kepercayaan) dan peribadatan kepada Tuhan Yang Maha Kuasa. Agama menurut Kamus Besar Bahasa Indonesia adalah sistem atau prinsip kepercayaan kepada Tuhan, atau juga disebut dengan nama Dewa atau nama lainnya dengan ajaran kebhaktian dan kewajiban-kewajiban yang bertalian dengan kepercayaan tersebut. Kata "agama" berasal dari bahasa Sansekerta agama yang berarti "tradisi". Sedangkan kata lain untuk menyatakan konsep ini adalah religi yang berasal dari bahasa Latin religio dan berakar pada kata kerja re-ligare yang berarti "mengikat kembali". Maksudnya dengan berreligi, seseorang mengikat dirinya kepada Tuhan (wikipedia.com). ${ }^{6}$ Secara teori pengertian agama dapat didekati dengan dua cara, yaitu secara etimologi dan terminologi. Etimologi mengulas dari sisi bahasa sedangan terminologi adalah proses mengkaji batasn-batasan dengan definisi atau bahasa ilmiah yang dibuat oleh para ahli agama dan ilmuwan. $^{7}$ Adapun penjelasan agama berdasarkan etimologi dan terminologi adalah sebagai berikut :

1. Pengertian secara Etimologis

Salah satu teori menjelaskan bahwa agama berasal dari akar kata gam, mendapat awalan "A" dan akhiran "A" sehingga menjadi A-gam-a. Akar kata agama ada pula yang mendapat awalan "I" dengan akhiran yang sama (menjadi I-gam-a) dan ada pula yang mendapat awalan "U" dengan akhiran yang sama (menjadi U-gama). Bahasa Sansekerta masuk rumpun bahasa Indo-Jerman. Dalam bahasa Belanda dan Inggris, anggota-anggota rumpun itu, ditemukan kata-kata ga, gaan (Belanda) dan go (Inggris) yang pengertiannya sama dengan gam yaitu pergi. Setelah mendapat awalan dan akhiran A pengertiannya berubah menjadi jalan. ${ }^{8}$ Orang Barat sendiri menyebut agama dengan religie atau religion. Kemudian bangsa Arab dan bangsa- 
bangsa selain Arab yang berbahasa dengan bahasa Arab menyebutnya dengan aldien. Selain para pemeluk agama Islam yang berbahasa dengan bahasa Arab menyebut agama dengan millah dan mazhab. ${ }^{9}$ Kata Ad-dien berasal dari kata kerja dayanya yang berarti hakama, yaitu hukum atau undang-undang sebagai pemegang tampuk kekuasaan dan kewibawaan.

2. Pengertian Agama secara Terminologis

Pengertian atau batasan tentang agama merupakan dasar untuk mempelajari agama sehingga diperlukan kajian terlebih dahulu sebelum melakukan pengkajian aspekaspek lainnya. Agama adalah tata aturan Tuhan yang berfungsi dan berperan, mendorong, memberi arah, bimbingan dan isi serta warna perilaku orang yang berakal dan mengembangkan potensi-potensi dasar yang dimiliki dan melaksanakan tugas-tugas hidupnya yang seimbang antara lahiriah dan batiniah dalam usahanya untuk memperoleh kesejahteraan hidup di dunia dan bekal kebahagiaan hidup di akherat kelak. ${ }^{9}$

\section{Kebudayaan}

Kebudayaan didefinisikan untuk pertama kali oleh E.B Taylor pada tahun 1871, dimana kebudayaan diartikan sebagai keseluruhan yang mencakup pengetahuan, kepercayaan, seni, moral, hukum, adat serta kemampuan dan kebiasaan lainnya yang diperoleh manusia sebagai anggota masyarakat. ${ }^{6}$ Kebudayaan dikenal karena adanya hasil-hasil atau unsur-unsurnya. Unsur-unsur kebudayaan terus menerus bertambah seiring dengan perkembangan hidup dan kehidupan. Manusia mengembangkan kebudayaan; kebudayaan berkembang karena manusia.

Manusia disebut makhluk yang berbudaya, jika ia mampu hidup dalam atau sesuai budayanya. Sebagian makhluk berbudaya, bukan saja bermakna mempertahankan nilainilai budaya masa lalu atau warisan nenek moyangnya; melainkan termasuk mengembangkan (hasil-hasil) kebudayaan. Kebudayaan diwujudkan dalam bentuk tata hidup yang merupakan kegiatan manusia yang mencerminkan nilai budaya yang dikandungnya. ${ }^{10}$

Di samping kerangka besar kebudayaan, manusia pada komunitasnya, dalam interaksinya mempunyai norma, nilai, serta kebiasaan turun temurun yang disebut tradisi. Tradisi biasanya dipertahankan apa adanya; namun kadangkala mengalami sedikit modifikasi akibat pengaruh luar ke dalam komunitas yang menjalankan tradisi tersebut. Perbedaan antara agama dan budaya tersebut menghasilkan hubungan antara iman-agama

\footnotetext{
${ }^{8}$ Sidi Gazalba, Ilmu Filsafat dan Islam Tentang Manusia dan Agama (Jakarta: Bulan Bintang,1978), hal. 95.

${ }^{9} \mathrm{~K}$ Sukardji, Agama-agama yang Berkembang di Dunia dan Pemeluknya (Bandung: Angkasa, 2007), hal. 26.

${ }^{10}$ Jujun S Suriasumantri, Filsafat Ilmu Sebuah Pengantar Populer, (Jakarta: Pustaka Sinar Harapan, 2006), hal. 261.
} 
dan kebudayaan sehingga memunculkan hubungan (bukan hubungan yang saling mengisi dan membangun) antara agama dan budaya.

\section{Hubungan Agama dan Kebudayaan}

Dalam awal perkembangannya, agama - agama di Indonesia telah menerima akomodasi budaya, seperti halnya dalam agama Islam dalam perkembangan dulu dapat dijelaskan dengan konsep Pertama, Islam sebagai konsepsi sosial budaya dan Islam sebagai realitas budaya. Kedua, Islam sebagai konsepsi budaya ini oleh para ahli sering disebut dengan great tradition (tradisibesar), sedangkan Islam sebagai realitas budaya disebut dengan little tradition (tradisi kecil) atau local tradition (tradisi local) atau juga Islamicate, bidang-bidang yang "Islamik" yang dipengaruhi Islam. ${ }^{5}$ Seperti halnya kebudayaan, agama sangat menekankan makna dan signifikasi sebuah tindakan karena terdapat hubungan yang sangat erat antara kebudayaan dan agama bahkan sulit dipahami kalau perkembangan sebuah kebudayaan dilepaskan dari pengaruh agama. Sesungguhnya tidak ada satupun kebudayaan yang seluruhnya didasarkan pada agama. Untuk sebagian kebudayaan juga terus ditantang oleh ilmu pengetahuan, moralitas secular, serta pemikiran kritis. Meskipun tidak dapat disamakan, agama dan kebudayaan dapat saling mempengarui. Agama mempengaruhi sistem kepercayaan serta praktik-praktik kehidupan. Sebaliknya kebudayaan pun dapat mempengaruhi agama, khususnya dalam hal bagaimana agama di interprestasikan / bagaimana ritual-ritualnya harus dipraktikkan.

Budaya yang digerakkan agama timbul dari proses interaksi manusia dengan kitab yang diyakini sebagai hasil daya kreatif pemeluk suatu agama tapi dikondisikan oleh konteks hidup pelakunya, yaitu faktor geografis, budaya dan beberapa kondisi yang objektif. Budaya agama tersebut akan terus tumbuh dan berkembang sejalan dengan perkembangan kesejarahan dalam kondisi objektif dari kehidupan penganutnya. Hubungan kebudayaan dan agama tidak saling merusak, kuduanya justru saling mendukung dan mempengruhi. Ada paradigma yang mengatakan bahwa " Manusia yang beragama pasti berbudaya tetapi manusia yang berbudaya belum tentu beragama”. Jadi agama dan kebudayaan sebenarnya tidak pernah bertentangan karena kebudayaan bukanlah sesuatu yang mati, tapi berkembang terus mengikuti perkembangan jaman. Demikian pula agama, selalu bisa berkembang di berbagai kebudayaan dan peradaban dunia. Kebudayaan menjadi perantara secara terus menerus yang dipelihara oleh pembentuknya dan generasi selanjutnya yang diwarisi kebudayaan tersebut. Sedangkan agama yang terdapat di masyarakat. 


\section{Peran Ilmu dalam pengembangan Agama}

Ilmu sebagai hasil aktivitas manusia yang mengkaji berbagai hal, baik diri manusia itu sendiri maupun realitas di luar dirinya, sepanjang sejarah perkembangannya, sampai saat ini selalu mengalami ketegangan dengan berbagai aspek lain dari kehidupan manusia. Pada dataran praktis operasional selalu diperbincangkan kembali hubungan timbal balik antara ilmu dan teknologi. Sering muncul polemik, terutama di Negara berkembang, manakah yang lebih penting antara mengembangkan ilmu murni dan ilmu dasar dengan mengembangkan teknologi melalui alih teknologi maupun industrialisasi ?. Apabila keduanya penting, bagaimana strategi yang seharusnya dibangun untuk mengembangkan keduanya mengingat keterbatasan sumber daya yang dimiliki rata-rata Negara berkembang? .

Adapun ciri atau syarat suatu ilmu ${ }^{11}$ adalah sebagai berikut:

1. Ada obyek yang diselidiki. Objek itu diselidiki sebagaimana adanya (Objektif).

2. Objek itu diselidiki dengan pendekatan (approach), cara atau metode tertentu, baik melalui pengamatan, analisa perbandingan, percobaan, metode induktif dan deduktif, yang keseluruhan mencakup riset (penelitian).

3. Objek yang telah dimengerti, diklarifikasi dengan kriteria tertentu.

4. Penyelidikan ini bertujuan bukan hanya memenuhi hasrat atau dorongan ingin tahu manusia, melainkan untuk memenuhi potensi dan kodrat kepribadian manusia bahwa hidupnya senantiasa bertujuan.

Ilmu seringkali dapat digunakan sebagai rujukan tambahan untuk memecahkan permasalahan pada kajian agama, bukan untuk memberikan masukan terhadap Agama. Dalam agama Islam, posisi ilmu pengetahuan dalam agama menjadi tema yang sentral. ini dapat ditemukan dalam beberapa teks, baik Al-Qur"an maupun hadist. Dalam AlQur'an, Allah menjanjikan derajat tinggi bagi mereka yang berilmu. ${ }^{12}$

\section{Peran Agama dalam pengembangan ilmu}

Agama merupakan salah satu entitas yang melekat dalam diri individu dan masyarakat. Secara defenitif, agama berasal dari bahasa Sanskerta "A Gama” yang berarti tidak kacau (gamang). Defenisi ini menunjukkan bahwa agama memiliki peran di dalam masyarakat agar hubungan antar individu di dalam masyarakat menjadi teratur dan menjaga agar setiap manusia senantiasa menjaga perilaku dan sifatnya dari hal - hal yang tidak terpuji. Ajaran - ajaran agama inilah yang menjadi dasar berperilaku manusia pada umumnya dan menjadi sesuatu yang sangat tinggi nilainya di dalam masyarakat.

\footnotetext{
$\overline{{ }^{11}}$ Mohammad Noor Syam, Filsafat Ilmu, (Malang:Univesitas Negeri Malang, 2006), hal. 110.
} 
Disinilah Agama dapat berfungsi sebagai penyeimbang terhadap segala permasalahan di masyarakat dan perkembangan ilmu.

Perkembangan ilmu di satu sisi berdampak positif karena dapat mempebaiki kualitas hidup manusia jika ditunjang teknologi, seperti pada bidang komunikasi, transportasi, medis dan sarana industri. Di sisi lain terkadang ilmu yang ditunjang teknologi dapat berdampak negatif karena merugikan dan membahayakan martabat manusia. Untuk menjelaskan peran agama terhadap perkembangan ilmu, maka dapat dilihat terlebih dahulu kemungkinan hubungan antara agama dan ilmu pengetahuan ${ }^{6}$ sebagai berikut :

- Pola hubungan yang negatif

Apa yang dianggap benar oleh agama dianggap tidak benar oleh ilmu pengetahuan dan teknologi. Demikian pula sebaliknya. Dalam pola hubungan seperti ini, pengembangan iptek akan menjauhkan orang dari keyakinan akan kebenaran agama dan pendalaman agama dapat menjauhkan orang dari keyakinan akan kebenaran ilmu pengetahuan.

- Pola perkembangan dari pola hubungan pertama

Ketika kebenaran iptek yang bertentangan dengan kebenaran agama makin tidak dapat disangkal sementara keyakinan akan kebenaran agama masih kuat di hati, jalan satu-satunya adalah menerima kebenaran keduanya dengan anggapan bahwa masing-masing mempunyai wilayah kebenaran yang berbeda.

- Pola hubungan netral

Kebenaran ajaran agama tidak bertentangan dengan kebenaran ilmu pengetahuan tetapi juga tidak saling mempengaruhi. Kendati ajaran agama tidak bertentangan dengan iptek, ajaran agama tidak dikaitkan dengan iptek sama sekali.

- Pola hubungan positif

Terjadinya pola hubungan seperti ini mensyaratkan tidak adanya pertentangan antara ajaran agama dan ilmu pengetahuan serta kehidupan masyarakat yang tidak sekuler. Secara teori, pola hubungan ini dapat terjadi dalam tiga wujud: ajaran agama mendukung pengembangan iptek tapi pengembangan iptek tidak mendukung ajaran agama, pengembangan iptek.

Ilmu pengetahuan tidak dapat menjawab permasalahan-pemasalahan tertentu dan filsafat memberikan solusinya. Untuk permasalahan- permasalahan tertentu filsafat tidak dapat memberikan jawaban yang memuaskan, maka manusia mencari jawaban yang pasti dengan berpaling kepada agama. Agama merupakan segenap kepercayaan, ajaran kebaktian dan kewajiban yang bertalian dengan kepercayaan tersebut.

${ }^{12}$ Lihat QS al-Mujadalah: 11 


\section{SIMPULAN}

Hakikat seorang manusia adalah untuk mencari kebenaran karena dibekali oleh Allah SWT dengan akal pikiran yang dibimbing oleh nilai - nilai agama. Ketiga aspek yang digunakan untuk mencari kebenaran di atas memiliki titik persamaan, titik perbedaan, dan hubungan antara satu dengan lainnya. Agama dan budaya berjalan beriringan sehingga memiliki hubungan yang erat dalam dialektikanya. Agama sebagai pedoman hidup manusia yang diciptakan oleh Tuhan, dalam menjalani kehidupannya. Sedangkan kebudayaan adalah sebagai kebiasaan tata cara hidup manusia yang diciptakan oleh manusia itu sendiri dari hasil daya cipta, rasa dan karsanya yang diberikan oleh Tuhan. Perkembangan ilmu di satu sisi berdampak positif karena dapat memperbaiki kualitas hidup manusia jika ditunjang teknologi, seperti pada bidang komunikasi, transportasi, medis dan sarana industri. Di sisi lain terkadang ilmu yang ditunjang teknologi dapat berdampak negatif karena merugikan dan membahayakan martabat manusia, sehingga diperlukan tatanan ajaran Agama untuk memberikan petunjuk.

\section{DAFTAR PUSTAKA}

Bagus, Lorens. 1996. Kamus Filsafat. Gramedia : Jakarta.

Bauto, Laode Monto . 2014. Perspektif Agama Dan Kebudayaan Dalam Kehidupan Masyarakat Indonesia. Jurnal Pendidikan Ilmu Sosial, Volume 23, No. 2, Edisi Desember.

Gazalba, Sidi. 1978. Ilmu Filsafat dan Islam Tentang Manusia dan Agama. Bulan Bintang : Jakarta.

Nur, Muhammad. 2015. Hakikat Agama dalam Perspektif Filsafat Perenial. Falsafatuna Jurnal Filsafat ISSN 2442-8981, E ISSN 2442-899X : Gorontalo.

Soegiono, Tamsil Muis. 2012. Filsafat Pendidikan. PT. Remaja Rosdakarya : Bandung.

Sukardji. 2007. Agama-agama yang Berkembang di Dunia dan Pemeluknya. Angkasa: Bandung.

Suriasumantri, Jujun. 2005. Filsafat Ilmu Sebuah Pengantar Populer. Pustaka Sinar Harapan : Jakarta.

Syam, Mohammad Noor. 2006. Filsafat Ilmu. Fakultas Ilmu Pendidikan Universitas Negeri Malang : Malang.

Utama, I Gusti . 2013. Filsafat Ilmu dan Logika. Diktat Filsafat Ilmu : Bali

Wahid, Abdul. 2014. Korelasi Agama, Filsafat Dan Ilmu. Jurnal Substantia, Vol. 14, No. 2, Oktober 2012. 